\title{
The Photosynthetic Light Dispensation System: application to microphytobenthic primary production measurements
}

\author{
Kirsten Wolfstein*, Peter Hartig** \\ Research and Technology Centre Westcoast, University of Kiel, D-25761 Büsum, Germany
}

\begin{abstract}
Measurements of microphytobenthos primary production were carried out in the German Wadden Sea in order to test the application of a 'Photosynthetic Light Dispensation System', which was originally developed for photosynthetic research of higher plants. A description of the computercontrolled system, consisting mainly of a subunit providing the irradiance (photosynthetically active radiation, PAR), and a subunit equipped with a Clark-type electrode for measuring oxygen production and respiration processes is given. The system allows rapid and reproducible measurements of photosynthesis-irradiance $(P-E)$ curves at light modes predetermined by the computer and simple, rapid data analysis. Additionally, $P-E$ curves obtained by this system were compared to those received by simultaneously conducted ${ }^{14} \mathrm{C}$ measurements. Primary production measured by the oxygen method was on average 2.00 times higher than the values obtained by the ${ }^{14} \mathrm{C}$ method. Production rates varied between 1.7 and $4.1 \mathrm{mg} \mathrm{C} \mathrm{mg} \mathrm{chl} a^{-1} \mathrm{~h}^{-1}$ with a mean of $2.75 \mathrm{mg} \mathrm{C} \mathrm{mg} \mathrm{chl} a^{-1} \mathrm{~h}^{-1}$
\end{abstract}

KEY WORDS: Photosynthetic Light Dispensation System - Primary production - Microphytobenthos German Wadden Sea

\section{INTRODUCTION}

Phytoplankton and benthic microalgae are important primary producers in the water column and on the tidal flats of the Wadden Sea, respectively (Cadée \& Hegeman 1974, Colijn 1984). A large number of investigations have focussed on the quantity of microphytobenthic biomass and primary production (Barranguet et al. 1996, McIntyre \& Cullen 1996), on the role of the algae in sediment stabilisation processes (Paterson 1990, Yallop et al. 1994) and on the physiological reactions of the algae with changing environmental conditions (Colijn \& van Buurt 1975, Admiraal 1977). Determination of microphytobenthic biomass and primary production is an important task in the monitoring of the Wadden Sea, because the algae provide up to a third of the total primary productivity,

\footnotetext{
- Present address: Sustainable Forest Management Network, G-208 Biological Science Building, University of Alberta, Edmonton, Alberta T6G 2E9, Canada

-Addressee for correspondence.

E-mail: hartig@ftz-west.uni-kiel.de
}

e.g. in estuarine systems (Sullivan \& Montcreiff 1988, Pinckney \& Zingmark 1993a, de Jonge 1995). However, due to the extremely heterogeneous distribution of algae, a large number of measurements is necessary to characterise a larger area on a monthly or annual basis, and therefore a quick and reliable measurement method is required. In the past, several methods for measuring primary production, such as the oxygen method (bell jars, microelectrodes) or the ${ }^{14} \mathrm{C}$ technique, have been used. The latter technique supplies data about the incorporated carbon, but an unknown amount of carbon is reassimilated, depending on the duration of incubation. The oxygen method using bell jars and oxygen electrodes provides net community production and community respiration data. During recent years, the use of microelectrodes has been established to measure 'in situ' benthic primary production (Hofman et al. 1991) providing the 'true' gross primary production (Revsbech \& Jørgensen 1986), the total produced quantity of oxygen without deducting the losses of oxygen-consuming processes. However, this method does not allow 
reproducible measurements under controlled environmental conditions. These are considered to be important for comparing photosynthetic capacities of algal populations by Dubinsky et al. (1987), who describe a system for measuring phytoplankton photosynthesis in a defined irradiance field with an oxygen electrode. In the present study, a comparable system, a so-called 'Light Dispensation System' in combination with a Clark-type electrode, was used to determine oxygen production of benthic algae. The electrode subunit is connected to a computer-controlled subunit supplying irradiance (photosynthetically active radiation, PAR), which allows measurements of photosynthesis-irradiance $(P-E)$ curves in reproducible irradiance conditions. For the photosynthetic parameters we have adopted the terminology of Sakshaug et al. (1997) The aim of this study was to test the application of the Photosynthetic Light Dispensation System to the measurement of benthic primary production, as up to now the system has only been used for photosynthetic research of higher plants and phytoplankton ( $E$. Brammer pers. comm.). Additionally, we compared the results obtained by this method to data from simultaneous ${ }^{14} \mathrm{C}$ measurements.

\section{MATERIAL AND METHODS}

Sampling. Samples were taken in June 1996 on the tidal flats of Keitum, located on the east coast of the island of Sylt in the German Wadden Sea $\left(8^{\circ} 23^{\prime} \mathrm{E}\right.$, $54^{\circ} 54^{\prime} \mathrm{N}$ ). At several locations, thin layers of the muddy sediment surface were scraped with a small spatula and collected in a jar. Because the Photosynthetic Light Dispensation. System was originally devel- oped for the measurement of algal suspensions, the algae had to be separated from the sediment. Therefore, the thoroughly mixed sample was transferred into $20 \times 30 \mathrm{~cm}$ containers and covered with 3 layers of lens tissue (Whatman 105).

The samples were pre-incubated at a constant irradiance of $70 \mu \mathrm{E} \mathrm{m}^{-2} \mathrm{~s}^{-1}$ during both day and night to stimulate algal migration and to enrich algal biomass on the tissues. Additionally, during the day some parallel samples were pre-incubated in the shade at $210 \pm$ $10 \mu \mathrm{E} \mathrm{m}^{-2} \mathrm{~s}^{-1}$ and in full sunlight at $1760 \pm 120 \mu \mathrm{E} \mathrm{m}^{-2}$ $\mathrm{s}^{-1}$. The following morning, the lens tissue together with the part of the microphytobenthos which was able to migrate into the thin tissue (Eaton \& Moss 1966) were harvested from the sediment. The algae in the upper 2 layers of the tissue (the lower layer was still contaminated with sediment) were resuspended in prefiltered (Whatman GF/C) water taken from small tide pools in the sampling area. The algal suspension was cleaned from tissue fibres by decanting over a small sponge in a funnel (Colijn \& van Buurt 1975). All measurements were conducted using this concentrated cell suspension.

Photosynthetic Light Dispensation System. Net primary production was measured in the laboratory as oxygen production by the Photosynthetic Light Dispensation System developed by ILLUMINOVA, Sweden. The apparatus consists of a system of 3 subunits connected to a computer (Fig. 1). One subunit (pfd dispenser; pfd: photon flux density) contains a $150 \mathrm{~W}$ halogen lamp emitting irradiances over a potential

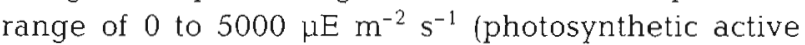
radiation). The irradiance is controlled by $3 \mathrm{LI}-189$ quantum sensors (Li-Cor). The first one is located in this unit to control the emitted irradiance, and the

\section{COMPUTER SCREEN}

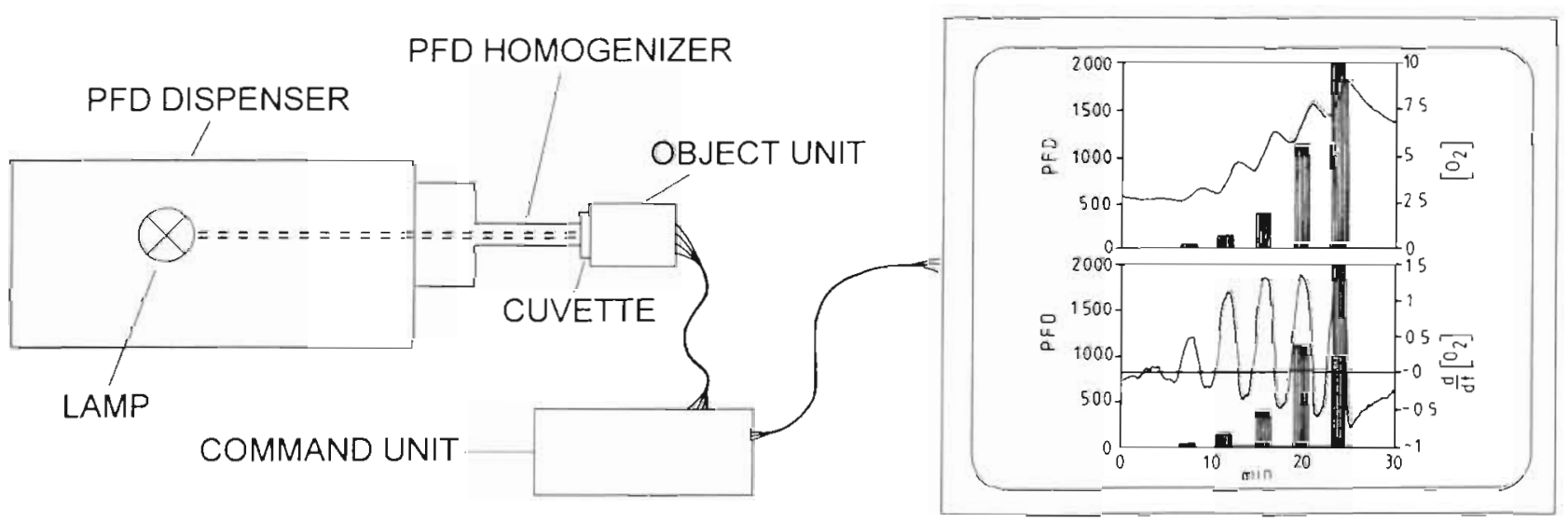

Fig. 1. Scheme of the Photosynthetic Light Dispensation System: pfd (photon flux density) dispenser with halogen lamp, object unit with measuring cuvette, command unit and computer screen showing an example of a measurements result, the absolute oxygen content and the change of the oxygen content per unit time at different irradiances 
second at one side of the measuring cuvette (part of the second subunit: object unit) to measure the quantity of light not reaching the cuvette. The third is located at the bottom of the cuvette to measure the absorbance of irradiance by the sample. Irradiance absorbance of the algal suspensions in the cuvette was always less than $10 \%$. Uniform illumination of the cuvette window was achieved by a light homogenizer, a polished aluminium tube which connects the pfd dispenser to the cuvette in such a way that all supplied light reached the cuvette window. The object unit contains the cuvette into which the $3 \mathrm{ml}$ sample is injected by a small syringe. The algal cells in the cuvette are kept in suspension by a small magnetic stirrer, driven by a $24 \mathrm{~V}$ motor located behind the cuvette. Oxygen concentration was measured by a Clark-type electrode MI-730 (response time <20 s; Microelectrodes Inc., USA), inserted at the back of the cuvette. The temperature of the measuring suspension was controlled by a connected refrigerated water bath. The third command unit connects the other subunits to the computer and is fitted with several controlling devices, e.g. for regulating the stirrer's velocity, to change between manual or computer-controlled measurements, and for calibration procedures, e.g. for adjusting zero and $100 \%$ oxygen saturation, as well as several vacant spaces for external light and $\mathrm{pH}$ meters.

Measuiring procedure. Each day prior to the measurements the system was calibrated against airsaturated seawater at the experimental temperature $(=100 \%)$, and against a $0 \%$ oxygen solution using a saturated $\mathrm{Na}_{2} \mathrm{SO}_{3}$ solution. One measurement of a $P-E$ curve took about $40 \mathrm{~min}$, and 2 parallel measurements of each sample were performed. Measurement started with 2 min of darkness, followed by a stepwise, successive increase of irradiance. Each irradiance step lasted for about $3 \mathrm{~min}$, and the samples were subjected to another 2 min of darkness at the end of the measurement to determine the respiration rate. Two different schemes of irradiance steps were tested: $7,12,20,40$, $55,80,125,220,335,400$ and $595 \mu \mathrm{E} \mathrm{m}^{-2} \mathrm{~s}^{-1}$ to obtain fine resolution of the initial slope of the curve, and 40 , $90,135,185,325,460,695,930,1160,1400$ and $1870 \mu \mathrm{E} \mathrm{m}^{-2} \mathrm{~s}^{-1}$ to span the range of maximum natural irradiances. The sample temperature during the measurement was held constant at $18 \pm 0.1^{\circ} \mathrm{C}$. All measured data loxygen concentration and changes with time, e.g. production as well as respiration, temperature, velocity of the stirrer, emitted irradiance by the pfd dispenser and irradiance measured at the bottom of the cuvette) were transferred immediately to the computer, allowing online-monitoring of the measurement in process. Data analysis was performed immediately afterwards using specifically developed software. Oxygen production was converted to carbon units using a factor of 0.32 , assuming a photosynthetic quotient (PQ) of 1.2 (Asmus 1982, Mills \& Wilkinson 1986), in order to compare the results to those obtained by the ${ }^{14} \mathrm{C}$ method (see 'Discussion').

${ }^{14} \mathrm{C}$ measurements. Aliquots $(2.5 \mathrm{ml})$ of the algal suspension were incubated simultaneously in a photosynthetron at $18 \pm 1^{\circ} \mathrm{C}$ (for more detailed description see Hartig et al. 1998, this volume). Irradiance was supplied by a quartz-halogen lamp, and the gradient of 11 different irradiances was generated by metal netting. Radioactive $\mathrm{NaH}^{14} \mathrm{CO}_{3}(0.5 \mu \mathrm{Ci})$ was added to glass vials containing the algal suspension and a known inorganic carbon content. After a $1 \mathrm{~h}$ incubation, the suspensions were filtered over a membrane filter of $0.45 \mu \mathrm{m}$ pore-size. Uptake of radioactive carbon was measured by a Tri-Carb 1900 TR, Packard Instruments, liquid scintillation counter.

All photosynthetic rate data $\left(\mathrm{O}_{2}\right.$ and $\left.{ }^{14} \mathrm{C}\right)$ were normalised to chlorophyll a. Photosynthetic efficiency $(\alpha)$ and the light saturation constant $\left(E_{k}\right)$ were calculated according to Megard et al. (1984).

Physical and chlorophyll measurements. Water temperature, $\mathrm{pH}$ and salinity were measured in small tide pools near the sampling locations. In situ irradiance was measured by a $2 \pi$ LI $Q 12331$ quantum sensor connected to a Li-1000 data-logger (Li-Cor, USA).

Water content of the sediment samples (in \%) was ralculated by subtracting the sediment dry weight from the wet weight, dividing this value by the wet weight, and multiplying the resulting value by 100 Dry weight was determined after drying the samples at $60^{\circ} \mathrm{C}$ for $24 \mathrm{~h}$. The organic content was calculated as loss on ignition (in \%) after combustion at $500^{\circ} \mathrm{C}$ for $2 \mathrm{~h}$ (Greiser 1988). As an index of algal biomass, chlorophyll a was determined using a Thermo Separation Products HPLC system according to the method of Mantoura \& Llewellyn (1983), as modified in Hartig et al. (1998).

In order to relate algal primary production to the dominant algal species, samples were inspected by light microscopy. To enable identification of the diatom species, organic cell compounds were removed by a treatment with sulphuric acid, potassium permanganate and oxalic acid (Hasle \& Fryxell 1970) and embedded in Naphrax.

\section{RESULTS}

\section{Environmental conditions, microphytobenthic biomass and dominant algal species}

Environmental conditions, e.g. temperature, salinity and $\mathrm{pH}$ of the small tide pools as well as water content and loss on ignition as a parameter for the organic con- 
Table 1 Environmental data from the sampling site at Keitum, Sylt, Germany

\begin{tabular}{|lccccc|}
\hline Date & $\begin{array}{c}\text { Water tem- } \\
\text { perature }\left({ }^{\circ} \mathrm{C}\right)\end{array}$ & Salinity & $\mathrm{pH}$ & $\begin{array}{c}\text { Water content } \\
(\%)\end{array}$ & $\begin{array}{c}\text { Loss on } \\
\text { ignition (\%) }\end{array}$ \\
\hline June 6.1996 & 26 & 24.5 & 8.17 & 68.9 & 11.3 \\
June 7.1996 & 26 & 29.3 & 7.96 & 69.3 & 11.8 \\
June 8.1996 & 25 & 35.9 & 8.06 & 69.7 & 12.5 \\
June 9.1996 & 20 & 31.6 & 8.0 & 55.2 & 8.9 \\
\hline
\end{tabular}

tent of the sediment, are presented in Table 1. Water content and the content of organic matter were very high, representative of muddy sediments (Figge et al 1988). Concentrations of chlorophyll $a$ in the algal suspensions obtained using the lens tissue technique, ranged between 0.138 and $2.587 \mathrm{mg} \mathrm{l}^{-1}$ (Table 2), but these values do not reflect natural conditions. Due to this technique, the suspension contained only motile algae, which were able to migrate into the tissues Dominant algae of this suspension were Gyrosigma acuminatum and Navicula flanatica, followed by Amphora coffaeformis and Navicula digitoradiata, which together amounted to approximately $90 \%$ of the total algal cells

\section{Photosynthetic parameters}

Maximal photosynthetic rates normalised to chlorophyll a $\left(P_{\max }^{B}\right)$, measured by the oxygen method in the laboratory, varied between 1.7 and $4.1 \mathrm{mg} \mathrm{C} \mathrm{mg}$ chl $\mathrm{a}^{-1}$ $\mathrm{h}^{-1}$ (mean of $2.75 \pm 0.69 \mathrm{mg} \mathrm{C} \mathrm{mg} \mathrm{chl} a^{-1} \mathrm{~h}^{-1}$ ) (Table 2), with the exception of 1 extremely high value of $11.1 \mathrm{mg}$ $\mathrm{C}$ mg chl $\mathrm{a}^{-1} \mathrm{~h}^{-1}$ on June 6 (omitted). Results obtained with the ${ }^{14} \mathrm{C}$ technique ranged between 0.66 and $1.72 \mathrm{mg} \mathrm{C} \mathrm{mg} \mathrm{chl} \mathrm{a}{ }^{-1} \mathrm{~h}^{-1}$ (mean of $1.23 \pm 0.46 \mathrm{mg} \mathrm{C} \mathrm{mg}$ chl $a^{-1} \mathrm{~h}^{-1}$ ). Maximal photosynthetic rate occurred between 350 and $500 \mu \mathrm{E} \mathrm{m} \mathrm{m}^{-2} \mathrm{~s}^{-1}$.
A few examples of the measured $P-E$ curves are shown in Fig 2. Measurements of $P-E$ curves were performed using a maximum provided irradiance

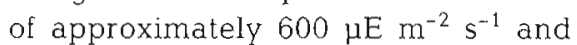
additionally, a maximum of approximately $1900 \mu \mathrm{E} \mathrm{m}^{-2} \mathrm{~s}^{-1}$, to span the range of natural maximum irradiances from 924 to $1933 \mu \mathrm{E} \mathrm{m}^{-2} \mathrm{~s}^{-1}$. The curves of both experiments mostly show a saturation of primary production between 300 and $500 \mu \mathrm{E} \mathrm{m}^{-2} \mathrm{~s}^{-1}$ A slight photoinhibition, e.g. decreasing oxygen production with increasing irradiance, mostly took place at irradiances above $400 \mu \mathrm{E} \mathrm{m} \mathrm{m}^{-2} \mathrm{~s}^{-1}$, which can be observed more clearly in Fig. 2B. Production rates showed a considerable variability during all days and did not seem to be influenced by lower light intensities and temperatures on June 9.

Community respiration (only algae and bacteria due to the lens tissue method) was measured at the end of each incubation and varied between 0.25 and $4.058 \mathrm{mg}$ $\mathrm{C} \mathrm{mg}$ chl $\mathrm{a}^{-1} \mathrm{~h}^{-1}$ which amounts to between 6 and $99 \%$ of primary production.

Physiological parameters of the algal suspensions, such as the photosynthetic efficiency $(\alpha)$ and the light saturation constant $\left(E_{k}\right)$, are listed in Table 3. $\alpha_{1}$ an indicator of efficient use of irradiance by algae, varied between 0.007 and 0.057 ( $\left.\mu \mathrm{g} \mathrm{C} \mu \mathrm{g} \mathrm{chl} a^{-1} \mathrm{~h}^{-1}\right)\left(\mu \mathrm{E} \mathrm{m} \mathrm{m}^{-2}\right.$ $\left.\mathrm{s}^{-1}\right)^{-1}$, showing the lowest values $[0.007$ to $0.023(\mu \mathrm{g} \mathrm{C}$

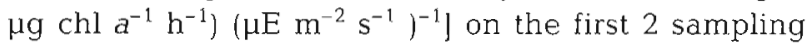
days and higher values $\left[0.016\right.$ to $0.057 \mathrm{f} \mu \mathrm{g} \mathrm{C} \mu \mathrm{g} \mathrm{chl} \mathrm{a}^{-1}$

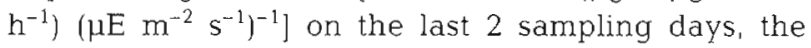
latter being related to measurements up to a maximum irradiance of approximately $1900 \mu \mathrm{E} \mathrm{m} \mathrm{m}^{-2} \mathrm{~s}^{-1}$. $E_{k}$ was between 55.82 and $297.48 \mu \mathrm{E} \mathrm{m}^{-2} \mathrm{~s}^{-1}$ and did not show any relationship to the different irradiances. It was, however, interesting that the values decreased after June 7

Table 2. Chlorophyll a content in the suspension and a comparison of photosynthetic rates $\left(P^{B}\right.$ max $)$ measured using the ${ }^{14} \mathrm{C}$ and $\mathrm{O}_{2}$ techniques (net $\mathrm{O}_{2}$ production data are mean values of 2 parallel measurements)

\begin{tabular}{|c|c|c|c|c|c|c|}
\hline Sample & & $\begin{array}{l}\text { Pre-incubation irradiance } \\
\text { of the sample }\left(\mu \mathrm{E} \mathrm{m}^{-2} \mathrm{~s}^{-1}\right)\end{array}$ & $\begin{array}{l}\text { Chlorophyll a } \\
\left(\mathrm{mg} \mathrm{l}^{-1}\right)\end{array}$ & $\begin{array}{c}{ }^{14} \mathrm{C} P^{B}{ }_{\max } \\
\left(\mathrm{mgC} \mathrm{mg} \mathrm{chl} d^{-1} \mathrm{~h}^{-1}\right)\end{array}$ & $\begin{array}{c}\mathrm{O}_{2} P_{\max }^{B} \\
\left(\mathrm{mgCmg} \mathrm{chl} a^{-1} \mathrm{~h}^{-1}\right)\end{array}$ & $\begin{array}{c}\text { Ratio } \\
\left(\mathrm{O}_{2} 1^{14} \mathrm{C}\right)\end{array}$ \\
\hline June 6, 1996 & $\begin{array}{l}a \\
b \\
c \\
d \\
e\end{array}$ & $\begin{array}{r}70 \\
210 \\
70 \\
210 \\
210\end{array}$ & $\begin{array}{l}0.175 \\
1.608 \\
0.138 \\
1.608 \\
1.608\end{array}$ & $\begin{array}{l}0.96 \\
1.38 \\
0.66 \\
1.62 \\
1.67\end{array}$ & $\begin{array}{l}1.70 \\
2.1 \\
2.3 \\
2.56 \\
2.60\end{array}$ & $\begin{array}{l}1.77 \\
1.52 \\
3.48 \\
158 \\
1.56\end{array}$ \\
\hline June 7, 1996 & $\begin{array}{l}\mathrm{a} \\
\mathrm{b}\end{array}$ & $\begin{array}{r}70 \\
1760\end{array}$ & $\begin{array}{l}0.420 \\
2.587\end{array}$ & $\begin{array}{l}1.59 \\
0.85\end{array}$ & $\begin{array}{l}2.83 \\
2.10\end{array}$ & $\begin{array}{l}1.78 \\
2.47\end{array}$ \\
\hline June 8, 1996 & $\begin{array}{l}a \\
b\end{array}$ & $\begin{array}{l}70 \\
70\end{array}$ & $\begin{array}{l}0.192 \\
0.192\end{array}$ & $\begin{array}{l}0.67 \\
0.66\end{array}$ & $\begin{array}{l}3.63 \\
4.10\end{array}$ & $\begin{array}{l}5.42 \\
6.21\end{array}$ \\
\hline June 9, 1996 & $\begin{array}{l}a \\
b\end{array}$ & $\begin{array}{l}70 \\
70\end{array}$ & $\begin{array}{l}1.132 \\
1.132\end{array}$ & $\begin{array}{l}1.61 \\
1.72\end{array}$ & $\begin{array}{l}3.22 \\
3.16\end{array}$ & $\begin{array}{l}2.00 \\
1.84\end{array}$ \\
\hline
\end{tabular}



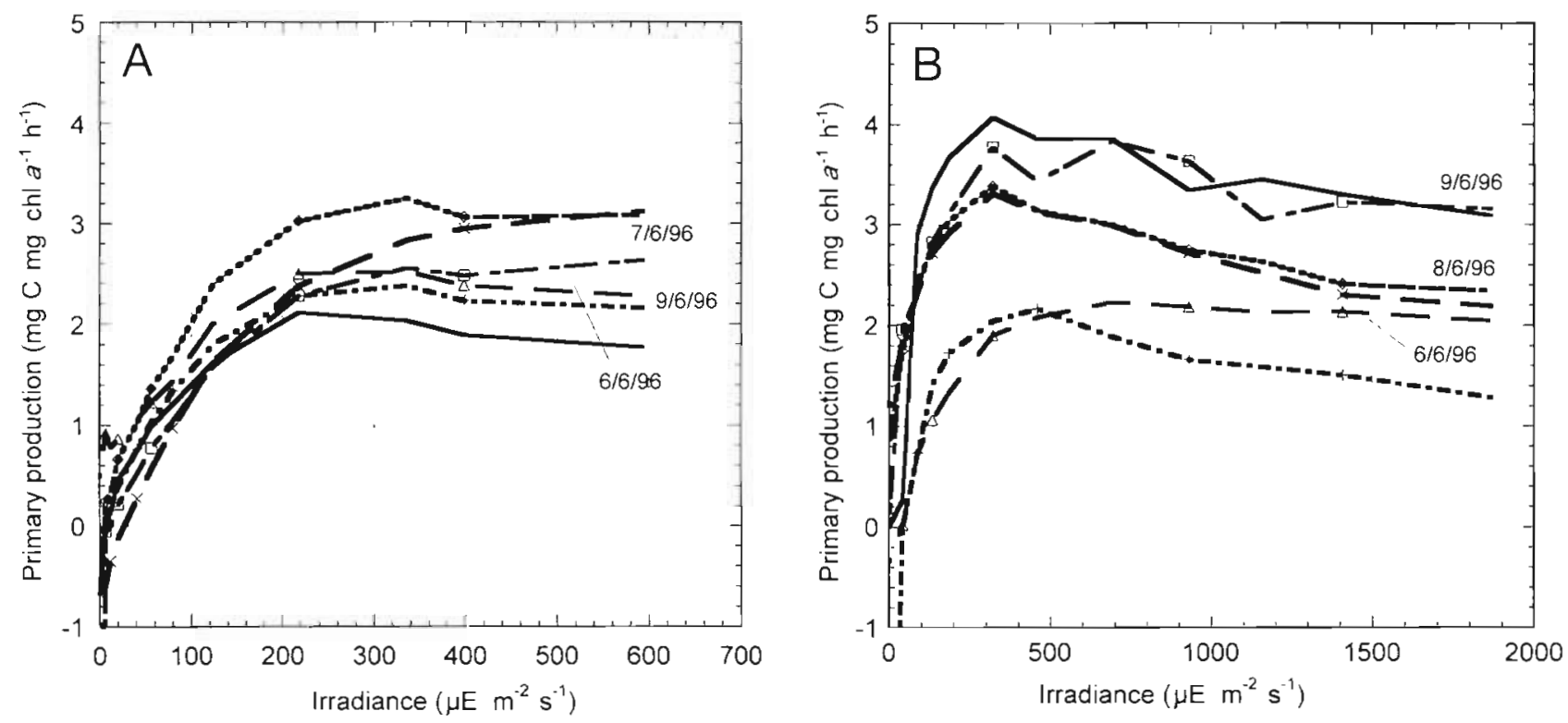

Fig. 2. Microphytobenthos primary production rates $\left(\mathrm{O}_{2}\right.$ technique) vs irradiances (A) from 0 to $595 \mu \mathrm{E} \mathrm{m}^{-2} \mathrm{~s}^{-1}$ and $(\mathrm{B})$ from 0 to $1870 \mu \mathrm{E} \mathrm{m}^{-2} \mathrm{~s}^{-1}$ Dates given as day/month/year

Table 3. Data of initial slope $(\alpha)$ of the photosynthesisirradiance $P-E$ curves and the light saturation constant $\left(E_{k}\right)$. $(\bullet)$ : values are related to measurements at the maximum irradiance of $1900 \mu \mathrm{E} \mathrm{m}^{-2} \mathrm{~s}^{-1}$

\begin{tabular}{|c|c|c|c|}
\hline Date & & $\begin{array}{c}\alpha \\
{\left[\left(\mu g C \mu g \operatorname{chl} a^{-1} h^{-1}\left(\mu E m^{-2} s^{-1}\right)^{-1}\right)\right.}\end{array}$ & $\begin{array}{c}E_{k_{k}} \\
\left(\mu E \mathrm{~m}^{-2} \mathrm{~s}^{-1}\right)\end{array}$ \\
\hline June 6, 1996 & ()$\left.^{\circ}\right)$ & $\begin{array}{l}0.017 \\
0.012 \\
0.009 \\
0.007\end{array}$ & $\begin{array}{l}136.77 \\
192.19 \\
190.05 \\
227.80\end{array}$ \\
\hline June 7, 1996 & & $\begin{array}{l}0.023 \\
0.011\end{array}$ & $\begin{array}{l}138.44 \\
297.48\end{array}$ \\
\hline June 8, 1996 & $(*)$ & $\begin{array}{l}0.044 \\
0.055\end{array}$ & $\begin{array}{l}93.8 \\
65.46\end{array}$ \\
\hline June 9, 1996 & $(\because)$ & $\begin{array}{l}0.057 \\
0.056 \\
0.016 \\
0.038\end{array}$ & $\begin{array}{r}56.65 \\
55.82 \\
147.34 \\
63.58\end{array}$ \\
\hline
\end{tabular}

\section{DISCUSSION}

\section{Application of the method}

The prime objective of our study was to test the application of the Photosynthetic Light Dispensation System to the measurement of primary production of microphytobenthos in its natural habitat. Several methods to measure microphytobenthic primary production are available. They all have their advantages and limitations, which are discussed elsewhere (Revsbech et al. 1981, Gätje 1992, Wiltshire et al. 1996). During this study, the limitation of the Photosynthetic Light Dispensation System was that only measurements on suspensions, obtained by the lens tissue method, could be conducted. Using this method to harvest microphytobenthos for the measurement of

Table 4. Maximum microphytobenthic photosynthesis rates from different areas

\begin{tabular}{|c|c|c|c|}
\hline Investigated area & $\begin{array}{c}P_{\max }^{B} \\
\left.\mathrm{~g} C \operatorname{mg} \operatorname{chl~} a^{-1} \mathrm{~h}^{-1}\right)\end{array}$ & Method & Source \\
\hline Ems-Dollard Estuary, Germany & $3.4-13$ & $\mathrm{O}_{2}$ (Clark-electr) Lens tissue & Admiraal \& Peletier (1980) \\
\hline Baffin Bay, Texas, USA & $2.98-20.01$ & ${ }^{14} \mathrm{C}$ Sediment core & Blanchard \& Montagna (1992) \\
\hline Ems-Dollard Estuary, Germany & 0.49 & ${ }^{14} \mathrm{C}$ Sediment core & Colijn \& de Jonge (1984) \\
\hline Elbe Estuary, Germany & 3.94 & $\mathrm{O}_{2}$ (Microelectr.) Sediment core & Gätje (1992) \\
\hline Bay of Fundy, Nova Scotia, Canad & $0.1-7$ & $\mathrm{O}_{2}$ (Clark-electr.) Sediment core & Hargrave et al. (1983) \\
\hline River Avon, Great Britain & 3.74 & $\mathrm{O}_{2}$ (Clark-electr.) Lens tissue & Mills \& Wilkinson (1986) \\
\hline Sylt, German Wadden Sea & $0.65-1.8,1.7-4.1$ & ${ }^{14} \mathrm{C} \mathrm{O}_{2}$ (Clark electr) Lens tissue & This study \\
\hline
\end{tabular}


Table 5. Comparison of the ratios of photosynthetic rates $\left(P_{\max }^{B}\right)$ measured by ${ }^{14} \mathrm{C}$ and $\mathrm{O}_{2}$ techniques using a $\mathrm{PQ}$ of 1.2 and 1.8

\begin{tabular}{|c|c|c|c|}
\hline Sample & $\begin{array}{c}\text { Pre-incubation } \\
\text { irradiance of the } \\
\text { sample }\left(\mu \mathrm{E} \mathrm{m} \mathrm{m}^{-2} \mathrm{~s}^{-1}\right)\end{array}$ & $\begin{array}{c}\text { Ratio }\left(\mathrm{O}_{2} / 14 \mathrm{C}\right) \\
P Q=1.2\end{array}$ & $\begin{array}{c}\text { Ratio }\left(\mathrm{O}_{2} /{ }^{14} \mathrm{C}\right) \\
\mathrm{PQ}=1.8\end{array}$ \\
\hline June 6, 1996 & $\begin{array}{c}(70) \\
(210) \\
(70) \\
(210) \\
(210)\end{array}$ & $\begin{array}{l}1.77 \\
1.52 \\
3.48 \\
1.58 \\
1.56\end{array}$ & $\begin{array}{l}1.16 \\
1.00 \\
2.29 \\
1.04 \\
1.02\end{array}$ \\
\hline June 7, 1996 & $\begin{array}{c}(70) \\
(1760)\end{array}$ & $\begin{array}{l}1.78 \\
2.47\end{array}$ & $\begin{array}{l}1.17 \\
1.62\end{array}$ \\
\hline June 8, 1996 & $\begin{array}{l}(70) \\
(70)\end{array}$ & $\begin{array}{l}5.42 \\
6.21\end{array}$ & $\begin{array}{l}3.56 \\
4.08\end{array}$ \\
\hline June 9, 1996 & $\begin{array}{l}(70) \\
(70)\end{array}$ & $\begin{array}{l}2.00 \\
1.84\end{array}$ & $\begin{array}{l}1.31 \\
1.21\end{array}$ \\
\hline
\end{tabular}

sensitive electrodes may emerge on the market which could be combined with the described system.

Until now this system has been used for photosynthesis studies on higher plants or macroalgae, but not for sediment-dwelling microalgae (E. Brammer pers. comm.). Additionally, the lens tissue technique had to be used during this study, because fluorescence induction kinetics of the microphytobenthos were measured at the same time by the pulse-amplitude modulated (PAM) fluorescence technique (Hartig et al. 1998). Both methods, the Photosynthetic Light Dispensation System and the PAM technique, were developed for photosynthetic

their primary production capacity is only an approximation of true 'in situ' conditions because it is not possible to measure the production of the whole community. The number of cells and species obtained by this method varies depending on the population composition. To estimate in situ rates, there is no alternative to measuring in undisturbed sediment cores. This has already been done by several workers (Revsbech \& Jørgensen 1986, Brotas et al. 1990, Gätje 1992) using microelectrodes.

The advantages of the Photosynthetic Light Dispensation System over the microelectrode method and the bell jar technique, however, is the precise control of environmental conditions such as irradiance and temperature, the supply of reproducible, rapid measurements of $P$-E curves and the measurement of physiological parameters in all requested light modes, predetermined by the computer. The latter is a new function, not included in a similar system described by Dubinsky et al. (1987). Additionally, there is the advantage of online-monitoring of the measurements, and data analysis is quite simple and rapid, because all data are immediately transferred to the connected computer, on which they are analysed by the integrated software and can be further processed by common calculation programs. Therefore, many measurements, e.g. using cultures of isolated microphytobenthic species, can be conducted very fast to study the physiology of the single species. The disadvantage of the oxygen method in comparison to the ${ }^{14} \mathrm{C}$ technique is the low sensivity of the Clark-electrode. The algal biomass of $0.138 \mathrm{mg}$ chl a $\mathrm{l}^{-1}$ in the measurements conducted on June 6 is considered to be a minimum if reliable production values are to be obtained. Therefore, the system cannot be used in conditions of lower algal biomass and when there is no possibility of enriching the algal suspensions. However, new, more research of higher plants or phytoplankton (Dubinsky et al. 1987, Edwards \& Baker 1993, Schreiber \& Bilger 1993) and were tested here for the first time for studies on microphytobenthic communities.

Future development steps would be to bring a known amount of sediment containing epipelic as well as epipsammic species into the cuvette to obtain information on physiological parameters of the total algal population. Moreover, it is an advantage to sample sediments of larger areas to get a mixed sample with an average value which could serve as baseline data for modelling microphytobenthic primary production.

\section{Comparison of the production rates and the photo- synthetic parameters with data of other studies}

It is generally very difficult to compare data of microphytobenthic production obtained by different authors, because different methods $\left(\mathrm{O}_{2},{ }^{14} \mathrm{C}\right)$, various incubation times, and in situ and laboratory incubations are used and also because in some studies primary production of the total algal population is investigated, whereas in others only that of the motile, epipelic algae is examined.

Nevertheless, it is common to compare primary production rates of different areas, despite the absence of a standardisation of the method (Gätje 1992, Pinckney \& Zingmark 1993b). The obtained production rates of this study were in the same range as those obtained by other authors using different methods and different algal composition (Table 4). In the present study, maximum photosynthetic rates of 1.7 to $4.1 \mathrm{mg} \mathrm{C} \mathrm{mg}$ $\mathrm{chl} \mathrm{a}^{-1} \mathrm{~h}^{-1}$ (with one exception of $11.1 \mathrm{mg} \mathrm{C} \mathrm{mg} \mathrm{chl} \mathrm{a}^{-1}$ $h^{-1}$ ) were measured with the oxygen method. These values are somewhat lower than the maximum photosynthetic rates found by Admiraal \& Peletier (1980) 
(3.4 to $13 \mathrm{mg} \mathrm{C} \mathrm{mg} \operatorname{chl~} \mathrm{a}^{-1} \mathrm{~h}^{-1}$ ) which were also obtained on algae collected using the lens tissue method. In our study, mean maximum photosynthetic rate $\mathrm{O}_{2}$ method, data were converted to carbon by using a factor of 0.32 assuming a $P Q$ of 1.2 ) was $2.75 \pm$ $0.69 \mathrm{mg} \mathrm{C} \mathrm{mg} \mathrm{chl} \mathrm{a}^{-1} \mathrm{~h}^{-1}\left({ }^{14} \mathrm{C}\right.$ technique: $1.23 \pm 0.46 \mathrm{mg}$ $\mathrm{C} \mathrm{mg} \mathrm{chl} \mathrm{a}^{-1} \mathrm{~h}^{-1}$ ). The photosynthetic rates found by Mills \& Wilkinson (1986), which were also obtained with algal suspensions harvested using the lens tissue method, were slightly higher than our data, which had a mean of $3.53 \mathrm{mg} \mathrm{C} \mathrm{mg} \mathrm{chl} \mathrm{a}^{-1} \mathrm{~h}^{-1}$. These elevated rates could be caused by the higher temperature during their measurements. The influence of temperature upon the rate of primary production has already been shown by Macintyre et al. (1996) and Blanchard et al. (1996). Pre-incubation at different irradiances, e.g. in the shade or in full sunlight, seemed to have no influence on the rate of primary production.

Primary production measured with the oxygen method was always higher than that measured with the ${ }^{14} \mathrm{C}$ method. The mean ratio of $\mathrm{O}_{2}$ and ${ }^{14} \mathrm{C}$ was $2.00 \pm 0.59$, excluding the extremely variable high ratios of June 8 . The relatively high production rates based on the oxygen method in comparison to the ${ }^{14} \mathrm{C}$ technique could be influenced by using a conversion factor of 0.32 ( $\mathrm{mg}$ oxygen to $\mathrm{mg}$ carbon; Asmus 1982, Mills \& Wilkinson 1986) and by the chosen PQ of 1.2 The choice of a higher $\mathrm{PQ}$ valuc, common in studies on phytoplankton production (Garcia \& Purdie 1994), would lead to a smaller difference; therefore, additional calculations using a PQ of 1.8 were conducted, resulting in less differences between the 2 methods (Table 5) with a mean ratio of $\mathrm{O}_{2}$ to ${ }^{14} \mathrm{C}$ of $1.31 \pm 0.39$. However, a lower PQ than 1.8 was chosen by most authors for microphytobenthic primary production, e.g. 1.0 (Hargrave et al. 1983, Barranguet et al. 1994), 1.2 (Asmus 1982, Mills \& Wilkinson 1986, Gätje 1992) and 1.3 (Colijn et al. 1983). The nitrogen source is important for the choice of $P Q$ : a higher $P Q(1.5$ to 1.8 ) should be taken when nitrate is assimilated and a lower value of approximately 1.25 should be used when ammonia is assimilated (Williams et al. 1979). The latter was true for the algal population at the sampling site of Keitum (R. Asmus pers. comm.).

The differences between the 2 methods could also be caused by the fact that the medium was kept in motion by a stirrer as opposed to the ${ }^{14} \mathrm{C}$ measurements (Hartig et al. 1998). Colijn \& de Jonge (1984) and Gould \& Gallagher (1990) proposed that the production of microalgae could be enhanced by stirring the overlying water over a sediment core. Also, H. Lindeboom in Colijn et al. (1983) observed a 4.3 to 8.8 higher production measured with the oxygen method (microelectrodes) compared to the ${ }^{14} \mathrm{C}$ technique. It also has to be considered that in this investigation the values obtained by the ${ }^{14} \mathrm{C}$ technique have to be regarded as gross production values because the incubation time was only $1 \mathrm{~h}$ (Fast 1993), whereas the results of the oxygen method of this study are net values. The differences in the results of the 2 methods could also be due to the different incubation procedures. During the measurements with the oxygen method, the sample was incubated for 40 min with successively increasing steps of irradiance. For the measurements using the ${ }^{14} \mathrm{C}$ technique, single incubations were conducted, i.e. each subsample was incubated for $1 \mathrm{~h}$ at a constant light intensity. In this context, Weger et al. (1989) mentioned that net photosynthetic oxygen evolution is higher when the cells are exposed to increasing irradiance levels than when they are exposed at constant irradiances.

In this study, the $P-E$ curves showed a steep initial slope, serving as an indicator of to what extent the algae may use low irradiances. This observation shows the very effective use of low irradiances by the algae. Photosynthetic efficiency $\alpha$ varied between 0.007 and $0.057\left(\mu \mathrm{gC} \mu \mathrm{g} c h l a^{-1} \mathrm{~h}^{-1}\right)\left(\mu \mathrm{E} \mathrm{m} \mathrm{m}^{-2} \mathrm{~s}^{-1}\right)^{-1}$, the latter being slightly higher than the values obtained by Blanchard et al. (1994) of between 0.01 and 0.02 ( $\mu \mathrm{g} \mathrm{C} \mu \mathrm{g}$ chl $\left.a^{-1} \mathrm{~h}^{-1}\right)\left(\mu \mathrm{E} \mathrm{m} \mathrm{m}^{-2} \mathrm{~s}^{-1}\right)^{-1}$, but lower than the values

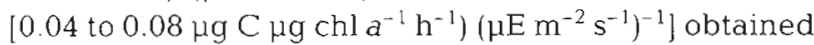
by Pinckney \& Zingmark (1993a). The light saturation constants $E_{k}$ of the latter studies were much higher (258 to $648 \mu \mathrm{E} \mathrm{m}^{-2} \mathrm{~s}^{-1}$ and 581 to $834 \mu \mathrm{E} \mathrm{m}^{-2} \mathrm{~s}^{-1}$, respectively) than those calculated during this investigation (56 to $297 \mu \mathrm{E} \mathrm{m}^{-2} \mathrm{~s}^{-1}$ ). Reaching a saturation plateau at lower irradiances may be considered to indicate that the algae are well adapted to low light conditions, which could be due to the pre-incubation at low irradiances. Another explanation may be that another factor was limiting photosynthesis, e.g. carbon dioxide, which could be possible due to the duration of a measurement and the small volume of the measuring cuvette. Differences between the parallel measurements (Table 3) may be caused by the inhomogeneity of the algal suspension or by the calculation program drawing the fit through the measured values.

It has to be considered that our production rates are related only to the motile, epipelic fraction of the algae, which could be caught by the lens tissue method. Therefore, the values should not be used as absolute values to characterise production capacities of this sampling station. When comparing the ratio of epipelic/ epipsammic algae of the total community, the various sediment types have to be considered. According to Varela \& Penas (1985), 60 to $75 \%$ of the total production of the algal population is due to epipsammic algae, whereas Brotas \& Catarino (1995) found that the epipelic biomass produce 8 to $87 \%$ of total chlorophyll a. However, MacIntyre et al. (1996) assume that 
migrating algae are likely to dominate microphytobenthic biomass and productivity. Species composition of the total algal population was not investigated, but at this sampling site migrating, epipelic algae dominate (K.-H. van Bernem pers. comm.). This is in agreement with the findings of Epping (1996), who concluded that epipelic diatoms inhabit the mud whereas epipsammic diatoms grow firmly attached to sand grains.

In conclusion, successful application of the Photosynthetic Light Dispensation System depends on the kind of investigations performed. For in situ measurements, the Photosynthetic Light Dispensation System may be problematic because of the described uncertainties. However, it proved to be useful for comparative purposes, e.g. investigation of seasonal variation of primary production. Especially for measurements of photosynthetic characteristics of algae, also of microphytobenthos, it seems to be a very suitable tool.

Acknowledgements. Thanks are due to the 'Biologische Anstalt Helgoland' for allowing us to work at their littoral station, to the GKSS research centre, to Sebastian Lippemeier for his support during the field investigations, to Britta Egge for technical assistance and to Franciscus Colijn and Marcus Reckermann for critical comments on a draft of the manuscript.

\section{LITERATURE CITED}

Admiraal WH (1977) Salinity tolerance of benthic estuarine diatoms tested with a rapid polarographic measurement of photosynthesis. Mar Biol 39:11-18

Admiraal W. Peletier H (1980) Influence of seasonal variations of temperature and light on the growth rate of cultures and natural populations of intertidal diatoms. Mar Ecol. Prog Ser 2:35-43

Asmus R (1982) Field measurements of seasonal variation of the activity of primary producers on a sandy tidal flat in the Northern Wadden Sea. Neth. J Sea Res 16:389-402

Barranguet C, Alliot E, Plante-Cuny MR (1994) Benthic microphytic activity at two Mediterranean shellfish cultivation sites with reference to benthic fluxes. Oceanol Acta 17:211-221

Barranguet C, Plante-Cuny MR, Alivon E (1996) Microphytobenthos production in the Gulf of Fos, French Mediterranean coast. Hydrobiologia 333:181-193

Blanchard GF, Gall VC (1994) Photosynthetic characteristics of microphytobenthos on Marennes-Oleron Bay, France: preliminary results. J Exp Mar Biol Ecol 182:1-14

Blanchard GF, Guarini JM, Richard P, Gros Ph, Mornet F (1996) Quantifying the short-term temperature effect on light saturated photosynthesis of intertidal microphytobenthos. Mar Ecol Prog Ser 134:309-313

Blanchard GF, Montagna PA (1992) Photosynthetic response of natural assemblages of marine benthic microalgae to short- and longterm variations of incident irradiance in Baffin Bay, Texas. J Phycol 28:7-14

Brotas V, Amorim-Ferreira A, Vale C, Catarino F (1990) Oxygen profiles in intertidal sediments of Ria Formosa (S. Portugal). Hydrobiologia 207:123-129

Brotas V, Catarino F (1995) Microphytobenthos primary pro- duction of Tagus Estuary intertidal flats (Portucfal). Neth J Aquat Ecol 29(3-4):333-339

Cadée GC, Hegeman J (1974) Primary production of the benthic microflora living on tidal flats in the Dutch Wadden Sea. Neth J Sea Res 8(2-3):260-291

Colijn F (1984) Characteristics of primary production in the Dutch Wadden Sea. Neth Inst Sea Res Publ Ser 10/84: $41-50$

Colijn F, de Jonge VN (1984) Primary productuon of microphytobenthos in the Ems-Dollard Estuary. Mar Ecol Prog Ser 14:185-196

Colijn F, Gieskes WWC, Zevenboom W (1983) The measurement of primary production: problems and recommendations. Hydrobiol Bull 17(1):29-51

Colijn $F$, van Buurt $G(197.5)$ Influence of light and temperature on the photosynthetic rate of marine benthic diatoms. Mar Biol 31:209-214

De Jonge VN (1995) Wind driven tidal and annual gross transports of mud and microphytobenthos in the Ems estuary, and its importance for the ecosystem. In: Dyer KR, Orth JR (eds) Changes in fluxes of estuaries. Olsen \& Olsen, Fredensborg, p 29-40

Dubinsky Z, Falkowski PG, Post AF, van Hes UM (1987) A system for measuring phytoplankton photosynthesis in a defined light field with an oxygen electrode. J Plankton Res 9:607-612

Eaton JW, Moss B (1966) The estimation of numbers and pigment content in epipelic populations. Limnol Oceanogr 11:584-595

Edwards GE, Baker NR (1993) Can $\mathrm{CO}_{2}$ assimilation in maize leaves be predicted accurately from chlorophyll fluorescence analysis? Photosynth Res 37:89-102

Epping HG (1996) Benthic phototrophic communities and the sediment-water exchange of oxygen, $\mathrm{Mn}(\mathrm{II}), \mathrm{Fe}(\mathrm{II})$, and silicic acid. PhD thesis, University of Groningen

Fast T (1993) Zur Dynamik von Biomasse und Primärproduktion des Phytoplanktons im Elbe-Ästuar PhD thesis, University of Hamburg

Figge K, Thiel HR, Wieland P (1988) Schlickuntersuchungen im Wattenmeer der Deutschen Bucht. Die Küste 35: $187-204$

Garcia VMT, Purdie DA (1994) Primary production studies during a Gyrodinium cf. aureolum (Dinophyceae) bloom in the western English Channel. Mar Biol 119:297-305

Gätje C (1992) Artenzusammensetzung, Biomasse und Primärproduktion des Mikrophytobenthos des Elbe-Ästuars. PhD thesis, University of Hamburg

Gould DM, Gallagher ED (1990) Field measurements of specific growth rate, biomass, and primary production of benthıc diatoms of Savin Hill. Cove, Boston. Limnol Oceanogr 35(8): 1757-1770

Greiser N (1988) Zur Dynamik von Schwebstoffen und ihren biologischen Komponenten in der Elbe bei Hamburg. Hamb Küstenforschung 45:1-169

Hargrave BT, Prouse NJ, Phillips GA, Neame PA (1983) Primary production and respiration in pelagic and benthic communities at two intertidal sites in the upper Bay of Fundy. Can J Fish Aquat Sci 40(Suppl 1):229-243

Hartig P, Wolfstein K, Lippemeier S, Colijn F (1998) Photosynthetic activity of natural microphytobenthos populations measured by fluorescence (PAM) and ${ }^{14} \mathrm{C}$-tracer methods: a comparison. Mar Ecol Prog Ser 166:53-62

Hasle GR, Fryxell GA (1970) Diatoms: cleaning and mounting for light and electron microscopy. Trans Am Microsc Soc 89:469-474

Hofman PAG, de Jong SA, Wagenvoort EJ, Sandee AJJ (1991) Apparent sediment diffusion coefficients for oxygen and 
oxygen consumption rates measured with microelectrodes and bell jars: application to oxygen budgets in estuarine intertidal sediments (Oosterschelde, S.W. Netherlands). Mar Ecol Prog Ser 69:191-196

Maclntyre HL, Cullen JJ (1996) Primary production by suspended and benthic microalgae in a turbid estuary: timescales of variability in San Antonio Bay, Texas. Mar Ecol Prog Ser 145:245-268

MacIntyre HL, Geider RJ, Miller DC (1996) Microphytobenthos: the ecological role of the 'secret garden' of unvegetated, shallow-water marine habitats. I. Distribution, abundance and primary production. Estuaries 19/2A:186-201

Mantoura RFC, Llewellyn CA (1983) The rapid determination of algal chlorophylls and carotinoid pigments and their breakdown products in natural waters by reverse-phase high performance liquid chromatography. Anal Chim Acta 151:297-314

Megard RO, Tonkyn DW, Senft WH (1984) Kinetics of oxygenic photosynthesis in planktonic algae. J Plankton Res 6:325-337

Mills DK, Wilkinson M (1986) Photosynthesis and light in estuarine benthic microalgae. Bot Mar 29:125-129

Paterson DM (1990) The influence of epipelic diatoms on the erodibility of an artificial sechment. In: Simola $\mathrm{H}$ (ed) Proc 10th Int Symp Living Fossil Diatoms, 1988, Joensuu. Otto Koeltz Science Publishers, Koenigstein/Taunus, p $345-355$

Pinckney JL, Znngmark RG (1993a) Photophysical responses of intertidal benthic microalgal communities to in situ light environments: methodological considerations. Limnol Oceanogr 38:1373-1383

Pinckney JL, Zingmark RG (1993b) Modelling the annual production of intertidal benthic microalgae in estuarine ecusystems. I Phycol 20:306-407

Revsbech NP, Jørgensen BB (1986) Microelectrodes: their use in microbial ecology. Adv Microb Ecol 9:273-352

Editorial responsibility: Otto Kinne (Editor),

Oldendorf/Luhe, Germany
Revsbech NP, Jorgensen BB, Brix BB (1981) Primary production of microalgae in sediments measured by oxygen microprofile, $\mathrm{H}^{14} \mathrm{CO}_{3}$-fixation, and oxygen exchange methods. Limnol Oceanogr 26:717-730

Sakshaug E, Bricaud A, Dandonneau Y, Falkowski PG, Kiefer DA, Legendre L, Morel A, Parslow J, Takahashi M (1997) Parameters of photosynthesis: definitions, theory and interpretation of results. J Plankton Res 19:1637-1670

Schreiber U, Bilger W (1993) Progress in chlorophyll fluorescence research: major developments during the past ten years in retrospect. In: Progress in Botany 54. SpringerVerlag, Berlin, p 151-173

Sullivan M, Montcreiff CA (1988) Primary production of edaphic algal communities in a Mississippi salt marsh. J Phycol 24:49-58

Varela M. Penas E (1985) Primary production of benthic microalgae in an intertidal sand flat of the Ria Arosa, NW Spain. Mar Ecol Prog Ser 25:111-119

Weger HG, Herzig R, Falkowski PG, Turpin DH (1989) Respiratory losses in the light in a marine diatom: measurements by short-term mass-spectrometry. Limnol Oceanogr 34:1153-1161

Williams PJleB, Raine RCT, Bryan JR (1979) Agreement between the ${ }^{14} \mathrm{C}$ and oxygen methods of measuring phytoplankton production: reassessment of the photosynthetic quotient. Oceanol Acta 2:411-416

Wiltshire KH, Schroeder F, Knauth HD, Kausch H (1996) Oxygen consumption and production rates and associated fluxes in sediment-water systems: a combination of microelectrode, incubation and modelling techniques. Arch Hydrobiol 137:457-486

Yallop M, de Winder B, Paterson D. Stal LJ (1994) Comparative structure, primary production and biogenic stahilisation of cohesive and non-cohesive sediments inhabited by microphytobenthos. Estuar Coast Shelf Sci 39: $565-582$

Submitted: December 8, 1997; Accepted: March 11, 1998 Proofs received from author(s): May 15, 1998 